\title{
Analysis and Generation of Japanese Folktales Based on Vladimir Propp's Methodology
}

\author{
Takenori Wama ${ }^{1}$, Ryohei Nakatsu ${ }^{2}$ \\ 1 Kwansei Gakuin University, School of Science and Technology \\ 2-1 Gakuen, Sanda, 669-1337 Japan \\ scbc0057@ksc.kwansei.ac.jp \\ http://www.ksc.kwansei.ac.jp \\ 2 National University of Singapore, Interactive \& Digital Media Institute \\ Block E3A, \#02-04, 7 Engineering Drive 1, Singapore 117574 \\ idmdir@nus.edu.sg \\ http://www.idmi.nus.edu.sg
}

\begin{abstract}
We aim to develop an automatic generation of interactive stories. For this aim, we have analyzed Japanese folktales. In this area, there exists famous research conducted by Vladimir Propp. He analyzed more than 100 Russian magicinspired folktales by segmenting each of them into a series of short segments and classified each segment into one of 31 functions. Here, we tried to analyze about 20 Japanese folktales adopting his method and found several interesting facts that differentiate Japanese folktales from those of Russia.
\end{abstract}

Keywords: Storytelling, Interactive Story, Folktales, Functions

\section{Introduction}

When we want to accomplish something, we always have some kind of story in mind. Furthermore, when we look back at our past, it appears as a series of events. This is the reason why it is sometimes said that "life is just like a story."

After all, story is an essential element in our lives. The existence itself of words such as "parody" and "homage," which imply artworks inspired by original works, means that the stories contained in various kinds of artworks have attracted many people.

Vladimir Propp [1] is the leading expert in the field of storytelling. He hypothesized that a story consists of a concatenation of short plots called "functions." Based on this idea, he analyzed more than 100 Russian magic-inspired folktales and found that about 30 functions are enough to construct all of the folk- 
tales. Of course, there were lots of predecessors. For example, the Brothers Grimm, known for "the Grimm Fairy Tales," collected various kinds of folktales, and such folktale collections helped in analyses of folktales. Although there were other classifications by Wundt and others at that time, Propp thought those classifications were not sufficient, especially in the case of Russian magic folktales. He succeeded in extracting the essence of "story" based on his concept of "function."

The approach described in this paper is based on Propp's idea. Our target is to develop an "Interactive Folktale System" taking Japanese folktales as an example, and for this purpose we analyzed Japanese folktales. If it were possible to classify not only magic folktales but also folktales in general, particularly Japanese ones in this work, according to his methodology, we could develop a database of "short stories" by segmenting Japanese folktales and try to develop a support system of story generation using the database.

As a famous tool for story generation, "Dramatica" [2] (Screen Play System, Inc.) has been developed for the US movie industry. It enables producers to drastically cut the cost of moviemaking, which is generally very expensive, and has attracted much attention. It asks users various questions concerning stories, and based on their answers gives them materials and advice for story generation. In Japan, too, the study of story generation has become active in recent years [3].

If we succeeded in constructing such automatic story generation systems or story-generation support systems, it would be very easy for any user, not only movie directors and screenplay writers, to generate stories at any time. This would result in greater diversity of contents and surely extend the range of "Entertainment" [4]. If we applied such a system in the field of education, it would help the process of juvenile cultivation of aesthetic sentiments. The following sections of this paper describe Propp's methodology and our analysis of Japanese folktales utilizing it.

\section{Theory and Background}

Vladimir Propp analyzed more that 100 magic-inspired Russian folktales based on the hypothesis that a story consists of a concatenation of short plots [1]. He tried to classify the short plots extracted from those magic folktales and found that there are 31 categories and that these are sufficient to construct all of the Russian magic folktales. However, as he himself pointed out, his methodology works well specifically for Russian magic folktales, which form a particular category among folktales in general. 


\subsection{Thirty-one Functions of Propp}

Propp arrived at an interesting conclusion through the process of analyzing Russian magic folktales. He found that different characters in the field of folktales achieve similar actions frequently. These acts are regularly used as universal material and fundamental components of folktales, and he called them "functions." Table 1 shows the 31 functions of Propp.

Based on his finding that the number of functions is restricted, he conjectured that the ordinal succession of functions in each magic folktale is always constant. Figure 1 shows the basic structure of the folktales found and proposed by him.

Table 1. Thirty-one functions

\begin{tabular}{|c|c|}
\hline \multicolumn{2}{|c|}{ [Code]Function } \\
\hline $\begin{array}{ll}0 . & {[\alpha] \text { Initial situation }} \\
1 . & {[\beta] \text { Absentation }} \\
2 . & {[\gamma] \text { Interdiction }} \\
\text { 3. } & {[\delta] \text { Violation }} \\
4 . & {[\varepsilon] \text { Reconnaissance }} \\
\text { 5. } & {[\zeta] \text { Delivery }} \\
6 . & {[\eta] \text { Trickery }} \\
\text { 7. } & {[\theta] \text { Complicity }} \\
\text { 8. } & {[\mathrm{A}] \text { Villainy }} \\
\text { 9. } & {[\mathrm{B}] \text { Mediation, the connective inci- }} \\
& \text { dent } \\
\text { 10. } & {[\mathrm{C}] \text { Consent to counteraction }} \\
\text { 11. } & {[\uparrow] \text { Departure, dispatch of the hero }} \\
& \text { from home } \\
\text { 12. } & {[\mathrm{D}] \text { The first function of the donor }} \\
\text { 13. } & {[\mathrm{E}] \text { Reaction of the hero }} \\
\text { 14. } & {[\mathrm{F}] \text { The acquisition, receipt of a }} \\
& \text { marginal agent } \\
\text { 15. } & {[\mathrm{G}] \text { Transference to a designated }} \\
& \text { place; guidance }\end{array}$ & $\begin{array}{ll}\text { 16. } & {[\mathrm{H}] \text { The hero struggles with the }} \\
& \text { villain } \\
\text { 17. } & {[\mathrm{J}] \text { Branding or marking the hero }} \\
\text { 18. } & {[\mathrm{I}] \text { Victory over the villain }} \\
\text { 19. } & {[\mathrm{K}] \text { The liquidation of misfor- }} \\
& \text { tune or lack } \\
\text { 20. } & {[\downarrow] \text { Return of the hero }} \\
21 . & {[\mathrm{Pr}] \text { Pursuit of the hero }} \\
22 . & {[\mathrm{Rs}] \text { Rescue of the hero }} \\
23 . & {[\mathrm{O}] \text { Unrecognized arrival }} \\
24 . & {[\mathrm{L}] \text { Claims of a false hero }} \\
25 . & {[\mathrm{M}] \text { Difficult task }} \\
26 . & {[\mathrm{N}] \text { Solution of a task }} \\
27 . & {[\mathrm{Q}] \text { Recognition of the hero }} \\
28 . & {[\mathrm{Ex}] \text { Exposure of the false hero }} \\
29 . & {[\mathrm{T}] \text { Transfiguration }} \\
30 . & {[\mathrm{U}] \text { Punishment of the false hero }} \\
& \text { or villain } \\
31 . & {[\mathrm{W}] \text { Wedding }}\end{array}$ \\
\hline
\end{tabular}




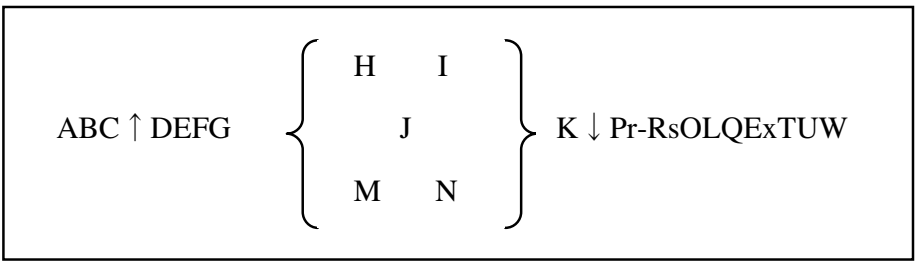

Fig. 1. Basic structure

\subsection{Signification and Potentiality}

As mentioned at the beginning of this chapter, Propp himself pointed out that the above rule holds true for Russian magic folktales but is not generally applicable to narratives, especially artificially produced tales. Propp's idea, in other words, represents only the characteristics of the Russian magic folktales he analyzed. Although some researchers tried to apply it to constructing a support system for story generation, in most cases the materials they study involve Russian magic folktales, similar to the work of Propp [5] [6]. Taking these situations into consideration, any attempt to apply his methodology to Japanese folktales would seem contradictory. However, if it could be shown that his methodology is applicable to Japanese folktales, this would imply that his idea could be applied to various fields, thus facilitating the construction of a system that can automatically generate various types of stories.

\section{Analysis of Story}

Japanese folktales are alive and well in diverse ways [7]. Folktales are essentially handed down orally from parent to child or from grandparent to grandchild. The descriptions used in relaying the story, as a matter of course, depend mainly on specific speakers who try to entertain their audience by telling these stories. This causes some differences even in the same folktale from one locality to another, or even from one family to another. We picked out more than 20 Japanese folktales from a popular folktale book [8] published in Japan for the purpose of maintaining consistency. In the following sections, analyses are given for "Momotaro" and "Click-Clack Mountain" as two examples of Japanese folktales. 


\section{1 "Momotaro"(The Adventures of a Peach boy)}

As is common in most folktales, the prologue of the story begins with the "Initial situation" $[\alpha]$ (ex. long, long time ago in a certain place...). The circumstances and scene including the main characters become clear, and then the story revolves around these characters.

Table 2 shows an analysis of "Momotaro." It begins with the "Initial situation" and revolves around Momotaro, a leading character. He grows up fast and comes to have a determination to get rid of the devils that are endangering the villagers. On the way to Demon's Island, he meets a dog, a monkey, and a pheasant, and he makes them his companions by giving them "Kibidango," a sweet millet dumpling. Up hill, down dale, and across the sea, his group finally arrives at their destination, Demon's Island. They punish devils to get back stolen property. Finally, they make a triumphant return to Momotaro's village. Figure 2 shows the structure of "Momotaro" based on the model of Figure 1.

Table 2. Analysis of "Momotaro"

\begin{tabular}{|c|c|}
\hline Text & Function \\
\hline $\begin{array}{l}\text { Long, long time ago in a certain place, there were some } \\
\text { grandparents. } \\
\qquad \text { *snip* }\end{array}$ & {$[\alpha$ ] Initial situation } \\
\hline $\begin{array}{l}\text { One day, when the grandmother was at the riverside doing } \\
\text { laundry, she saw a big peach floating down from upriver. } \\
\qquad \text { *snip* }\end{array}$ & $\begin{array}{l}\text { [Q] Recognition of the } \\
\text { hero }\end{array}$ \\
\hline $\begin{array}{l}\text { Up hill and down dale, Momotaro and his group got to the } \\
\text { seashore. } \\
\qquad \text { *snip* }\end{array}$ & $\begin{array}{l}{[\mathrm{G}] \text { Transference to a }} \\
\text { designated place }\end{array}$ \\
\hline $\begin{array}{l}\text { "I'm Momotaro, the strongest in Japan, punishing you devils!" } \\
\qquad \text { *snip* }^{\text {(n) }}\end{array}$ & $\begin{array}{l}{[\mathrm{H}] \text { The hero struggles }} \\
\text { with the villain }\end{array}$ \\
\hline They made it back to his Grandparents safely. & {$[\downarrow]$ Return of the hero } \\
\hline
\end{tabular}




\section{$\alpha \mathrm{QBC} \uparrow \mathrm{DEFDEFDEFGHI} \downarrow$}

Fig. 2. Structure of "Momotaro"

\section{2 “Click-Clack Mountain" (Return of a Rabbit)}

Table 3 shows an analysis of "Click-Clack Mountain." It also begins with the "Initial situation," and the main characters, again Grandparents, are explained in turn. Although the grandfather punishes a mischievous raccoon, the grandmother is killed by this shifty animal while the grandfather is away. He is disconsolate at her death, and then a rabbit, a friend of the Grandparents, inspires the determination to seek revenge against the raccoon for the murder. The rabbit burns the raccoon at the stake using flint, hitting the notes "Click-Clack," the onomatopoeia behind this folktale, and rubs pepper, disguised as medicine, into the raccoon's wounds. Finally, the rabbit puts the raccoon in a ship of mud and sinks it with the raccoon to the bottom of the river. Figure 3 shows the structure of "Click-Clack Mountain" based on the model of Figure 1.

Table 3. Analysis of "Click-Clack Mountain"

\begin{tabular}{|c|c|}
\hline Text & Function \\
\hline $\begin{array}{l}\text { Long, long ago in a certain place, there were some good- } \\
\text { hearted Grandparents. } \\
\qquad \text { *snip* }^{\text {s. }}\end{array}$ & {$[\alpha]$ Initial situation } \\
\hline $\begin{array}{l}\text { Grandfather caught Raccoon swathed in a rope. } \\
\qquad \text { *snip* }\end{array}$ & $\begin{array}{l}{[\mathrm{U}] \text { Punishment of a false }} \\
\text { hero or villain }\end{array}$ \\
\hline $\begin{array}{l}\text { Shifty Raccoon had an evil design to get out of here. } \\
\qquad \text { *snip* }^{\text {s. }}\end{array}$ & {$[\eta]$ Trickery } \\
\hline $\begin{array}{l}\text { Rabbit living in the front mountain, seeing Grandfather dis- } \\
\text { consolate at her death, consoled him and gave him the deter- } \\
\text { mination to avenge himself on Raccoon. } \\
\qquad \text { *snip* }\end{array}$ & $\begin{array}{l}{[\mathrm{C}] \text { Consent to counter- }} \\
\text { action }\end{array}$ \\
\hline
\end{tabular}




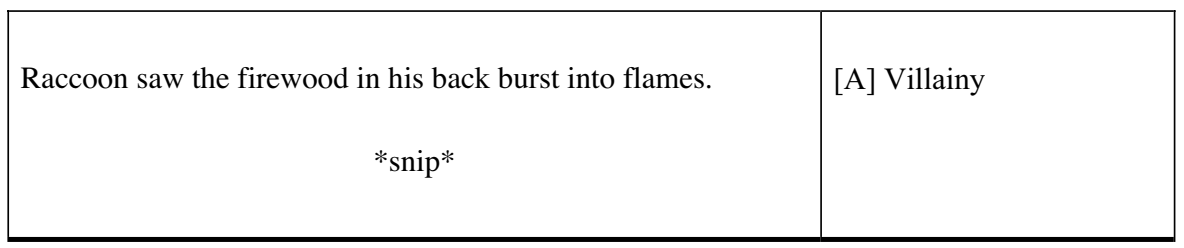

\section{$\alpha \mathrm{BCU} \beta \eta \theta \mathrm{ABC} \uparrow \eta \theta \mathrm{A} \eta \theta \mathrm{A} \eta \theta \mathrm{A}$}

Fig. 3. Structure of "Click-Clack Mountain"

\section{Discussion}

"Function" as defined by Propp represents just the action of the characters. In other words, function itself contains a role of subject or object in a short scene. For example, with the eleventh function in Table 1, [ $\uparrow$ ] Departure, the composition of "the hero leaves his home" is predetermined. Also for the eighteenth function, [I] Victory over the villain, the condition that "A works on B" is included in the function. In this case, $\mathrm{A}$ is a hero and $\mathrm{B}$ is a villain (a hero defeated a villain) or A is a villain and B is a hero (villain is defeated by a hero). From these examples, it seems the reason why the roles of main characters are included in the definition of each function is that the main characters have some kind of symbolism. Devils in "Momotaro" and Raccoon in "Click-Clack Mountain" are emblematic of an adversary that threatens the lives and livelihoods of people. Furthermore, we can assume that Propp realized the symbolism in the magic folktales he analyzed, so he may have hypothesized the concatenation of short plots called "functions" as having a role system of subject-object relationships. Through our analysis, we found that this is true in the case of Japanese folktales.

We noted an interesting factor while analyzing more than 20 Japanese folktales based on Propp's methodology. Rabbit in "Click-Clack Mountain" plays second fiddle in the early part, which features Grandparents and Raccoon; however, Rabbit stands in the spotlight, as if a leading character, in the later part of the story. On the other hand, "Momotaro" has a clearly established role of hero, and the behavior of each character changes little in this story. This seems to suggest that a certain regularity may be found by analyzing Japanese folktales in more detail.

A new classification of Japanese folktales taking a different approach from Propp's idea is also under review. Table 4 shows four provisional groups of Japanese folktales. We hypothesized that folktales classified as "Grand Finale" bring the story to an end by punishing villains, or otherwise resolving a problem, as seen 
in "Momotaro." The group called "Anecdote of Birth" contains stories about the origin of names and beings. "Divine Justice" includes stories teaching that "as you sow, so shall you reap,' such as "Click-Clack Mountain." Finally, "Estrangement" involves stories that stage a final parting scene. Perhaps our future analysis will alter or refine these four tendencies, but in any case a methodology distinct from Propp's idea will help in developing a novel model of story generation.

Table 4. Four provisional story groups

\begin{tabular}{ll}
\hline 1. & Grand Finale \\
2. & Anecdote of Birth \\
3. & Divine Justice \\
4. & Estrangement \\
\hline
\end{tabular}

\section{Conclusions}

This paper describes the approach of applying Propp's methodology to a category of Japanese folktales. We anticipated many hurdles because we tried to analyze Japanese folktales rather than the Russian ones he analyzed. However, we could successfully analyze 20 representative Japanese folktales by utilizing the 31 functions defined by Propp. At the same time, we found that there is no single basic storyline, as in the case of Russian folktales, but several basic storylines. By carefully analyzing each story, we found that there are basically four representative storylines in the case of Japanese folktales: grand finale, anecdote of origin, divine justice, and estrangement. We also found interesting phenomena such as the role of character behavior, i.e., whether there are any transitions in a character's behavior, and a methodology distinct from Propp's was explored. Based on our findings, we are now trying to develop a model of generating Japanese folktales. This will require, in keeping with this approach, an increase in the number of analyzed folktales beyond 20 , from the viewpoint of developing a model. In addition, we should not only make a database of "stories" according to their "function" segmentations but also develop a support system for story generation using our own way of concatenating short plots. As the concept of "storytelling" [9] has recently attracted much attention, we can expect that related fields will become even hotter pursuits in the future.

\section{References}

1. Propp, V. (1968). Morphology of the Folktale. University of Texas Press. 
2. Tutani, Y. YUZI's INDIE FILMMAKER. (2003).

http://www.voltage.co.jp/indiefm/dramatica/dramatica1.htm.

3. Kaneko, M. Scenario Engine Project. (2003). http://www.teu.ac.jp/clab/orc/pdf/scenario2003.pdf.

4. Nakatsu, R. \& Rauterberg, M. A New Framework for Entertainment Computing: From Passive to Active Experience. (2005). In: F. Kishino et al. (Eds.), Entertainment Computing ICEC'05 (pp.1-12). Lecture Notes in Computer Science, Vol.3711, Springer Press..

5. Sakuma, T. \& Ogata, T. Story Generation Support System used the Story Theory of Propp. (2005). The $19^{\text {th }}$ Annual Conference of the Japanese Society for Artificial Intelligence, 3D3-04.

6. Sakuma, T. \& Ogata, T. The Synthesis of Stories using Combine Rules: An Approach for the Story Generation Support System with Automatic Story Generation Function. (2006). The $20^{\text {th }}$ Annual Conference of the Japanese Society for Artificial Intelligence, 2E3-2.

7. Inada, K. Japanese Folktales Hand Book. (2001). Sanseido Publisher.

8. Tomomi, K. Classical Edition: Japanese Folktales 101. (1997). Kodansha.

9. Murray, J. H. Hamlet on the Holodeck: The Future of Narrative in Cyberspace. (1997). Free Press. 